$\left(\mathrm{C}_{20} \mathrm{H}_{34} \mathrm{O}_{2} \mathrm{Br}_{6}\right.$ は臭素含量 61.02\%、 $\mathrm{C}_{22} \mathrm{H}_{38} \mathrm{O}_{2} \mathrm{Br}_{6}$ は臭素含量 53.92\%) 石油エーテル不溶性臭化物は暗橙 赤色粘稠なる飴狀物質にして巳に多少分解せる徵候を示せるを以て 其臭素含量より原脂肪酸つ 組成を確知し 難きも第二表 C に示せる收量及び臭素含量によれば 水素添加の經過中石油エーテル不溶性臭化物を生ずる $\mathrm{C}_{\mathrm{n}} \mathrm{H}_{2 \mathrm{n}-6} \mathrm{O}_{2}$ 列の酸及び恐らく $\mathrm{C}_{\mathrm{n}} \mathrm{H}_{2 \mathrm{n}-4} \mathrm{O}_{2}$ 列の酸も或程度に生成するものと考へらる

\title{
（4）白金觸媒の場合とニッケル觸媒の場合との比較
}

上記實驗結果を通覽して之を前報に於けるニッケル觸媒を用ひし場合と比較するにニッケル觸媒を用ひし場合 にはエーテル不溶性臭化物を生ずる高度不飽和酸が殆ど消失する迄は固體酸を著量には生成せずェーテル不溶 性臭化物を生ずる高度不领和酸が殁ど消失するや固體酸の量は急速に增加せり然るに本報に於汁る日金觸媒を 用ひし場合には水素添加の初期に於て已に固體酸を生成しエーテル不溶性臭化物を生ずる高度不飽和酸が殆ど 消失する點に於ては著量の固體酸を生成せりエーテル不溶性臭化物を生ずる高度不飽和酸が殘存せる範圍に於 て沃素偪闰じ點まで低下せる試料を此較すれば白金觸媒を用ひしものはニッケル觸媒を用ひしものよりエーテ ル不溶性臭化物を生ずる高度不飽和酸を多量に含有すると共に固體酸をも多量に含有寸今高度不飽和酸メチル エステルの水素涯加に於てエーテル不溶性臭化物を生ずる高度不飽和酸の消失する反應を $\mathrm{A}$ とし固逼酸の生 成する反應を B とせば上述の如くニッケル觸媒の場合には先づ A なる反應が主として淮行し B なる反應の 大部分は A なる反應が殆ど完了せる後に行はる郎ち A、Bなる二反應は殆ど完全に選擇的に進行寸之に反し 白金觸媒の場合には A なる反應が進行すると同時に $\mathrm{B}$ なる反㷳も或程度に進行す

ニッケル觸媒を用ふるか白金觸媒を用ふるかに從ひて高度不飽和酸メチルェステルの水素添加の經過が上記 の如く相違することは最近りチャードッン氏等（A. S. Richardson and A. O. Snoddy, Ind. Eng. Chem., 1926, 18，570汃棉實油つ水素添加に於て認めたる事實と相類似する所せり同氏等は棉實油の水素添加の經過 に就てニッケル觸媒を用ひし場合と白金觸媒を用ひし場合とを比較せるに白金觸媒の場合はニッケル觸媒の場合 程水素添加が選擇的ならざることを認めたり即ち棉實油の水素添加に於てオレイン酸（罢性體を含む）の增加 を $\mathrm{b} \%$ としステアリン酸の增加を $\mathrm{c} \%$ とせば同一の程度に水素涯加せるときの $\mathrm{b} ; \mathrm{c}$ はニッケル觸媒に比し白 金触媒のオが小なりと云ら.

\section{セメントの聯結硬化の强度と化學成分（第三報） 長期の聯結硬化及び空中硬化の强度}

（東京帝國大學工學部應用化學科鱓機工業化學咞究室）（昭和三年九月一四日受理）

工學士 永井 彰一 即

$$
\text { I 緒 } \overline{\overline{\bar{n}}}
$$

暴に第一及び第二報に於て低珃酸型及び高珠酸型の兩型種セメントのモルタルの聯結硬化强度と普通硬化强 度との羑異はセメントの化學成分と密按なる關俰を有することを確證したり郎た第一報に於ては兩型種セメ ントの水硬素たる石灰、珪酸、攀士、酸化鐵等の間に存する榙種の係數及び比率と聯結硬化强度が普通硬化强 度に對する增淮率との留係に就て研究し更に第二報に於ては拄酸三石灰、珪酸二石灰、礬土酸三石灰等の水硬 性化合物の生成量に關する新しき係數又は比窈を提案し是等と聯結硬化に依る强度堙進率との關係に就て研究 
したるところを報告したり

本報に於ては此の聯結硬化の方法に關して從來一般に行はるる 1 週間水中硬化後 3 週間空中硬化を聯結する 4 週聯結硬化 (之を普通聯結と稱して區別す) の後牛期の空中硬化期間を 3 週間より長短種々の期間（主とし て長期間とす)にしたる長期聯結硬化法に法りて其の强度が兩型種セメントに依りて如何なる差巽を示すべき かを比較研究したり此の長期聯結硬化の强度は高珪酸型セメントに於て著しく不利にして低珪酸型セメントに 於ては優良なる結果を與へ從つてセメントの種別に㑈りて空中工事たる建築工事用セメント及び地中工事たる 土木工事用セメントとしての適否に關し濕著なる差異を有することを確むることを得たり

更に是等聯結硬化法の最初の水中硬化期間の 1 週間に就て比較研究の䈑め水中硬化期間の皆無なる全期間空 中硬化のみの强度と他面には水中硬化期間を延長して4週間の後初めて空中硬化を聯結したる特殊聯結硬化(以 下之に倣ふつに传る强度とを比較研究して水中硬化の期間は約 1 週間を以つて充分に且つ必要なるのみならず 低珪酸型セメントに於ては餘り長期の水中硬化は却つて其の强度を害寸ること著しきを以て之れ亦土木、建筑 上セメントの使用に關して重要悓すべき點なることを確めたり

普通硬化法は水中硬化法なるに對し全材薮期間を空中硬化のみとしたる空中硬化法に依る强度が兩型種セメ ントに体りて如何なる差巽を有するかに關して比較研究し之を更に前述の長期聯結硬化、特殊聯結硬化、普通 硬化（或は水中硬化）に依る强度等と比較研究して空中硬化のみにては强度小にして特に高珠酸型セメントに 於て著しく强度の小なるを認め或る期間は必ず允分の水量がセメントの硬化及で强度の霄大に關し極めて重要 なることを確證し得たり

\section{II 長期の普通聯結硬化の强度}

普通聯結硬化の 1 週間水中硬化後 3 週間空中硬化せしむる期間を延長したる長期聯結硬化法に關する著者の 咑究の牛ば淮みたる時に於て獨逸のへーゲルマン氏(G. Haegermann：Tonind.=Ztg., 1928, 52, 119; Concrete, 1928, 32, No. 3, 106) は數種のセメントに就て略同樣の長期聯結硬化の强度訊驗結果を發表したるを 初めキュール氏 (H. Kühl : Tonind.=Ztg., 1928, 52, 870) の研究發表、カイト（J. Keith）、キュール、ーーゲ ルマン氏等の論爭(Tonind. =Ztg., 1928, 53, 1100)等を初め此の長期の聯結硬化の問題は今や愈々重要視せら

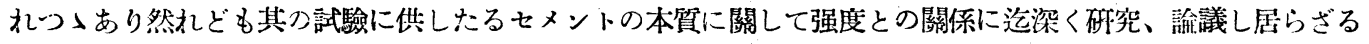
もの>如し著者は第一報の緒言に於て述べたる如く聯結硬化强度が普通硬化强度に對寸る習淮率は主としてセ メントの化學成分と密接なる 關係を有すべきを以て本報つ研究を初めたるものにして既に第一報第四表（本 誌、1928、31、824）に表示したる如く其の化學成分つ藷しく相翼する低珪酸型及び高理酸型の兩型種セメント に就て此の長期の聯結硬化の强度と化學成分との㗊係を究めんが爲めに諸種の比較試驗をなしたり

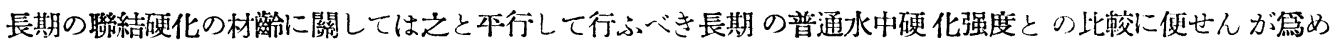
（1）1週、（2）2週、(3) 4週、(4) 8䓢、(5)13週、(6)26週（約 6個月）の全村齡を水中硬化したる普通硬化に 對し最初の 1 週間水中硬化したる後空中硬化に移し從つて空中硬化期間は（2）1掘、(3) 3週、(4) 7逓、(5)12 週、(6)25 週となしたる長期聯結硬化を比較したり故に水中硬化と聯結硬化とは何れる成形より試驗迄の全材

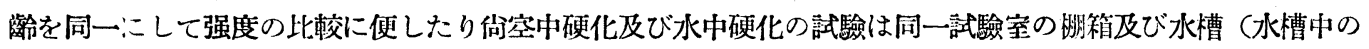
水溫は殆儿ど室溫に保なしめ) 中に置き溫度の差を充分小ならしめ其の他成形時の諸條件は努めて同一に保て り

本試驗に供したるセメントは第一報第一表より第四表迄に此較したる低珠酸型及び高珪酸型より各 2 種宛を 
選出して使用したるものにして次に第一及び第二表に於て長期の水中硬化と聯結硬化との强廉及び前者に對す る後者の比率を表示柱らし

第一表 長期の氷中及び聯繥硬化に依方抗張力と比率

セメント試料 硬化法

種别番號 と比率

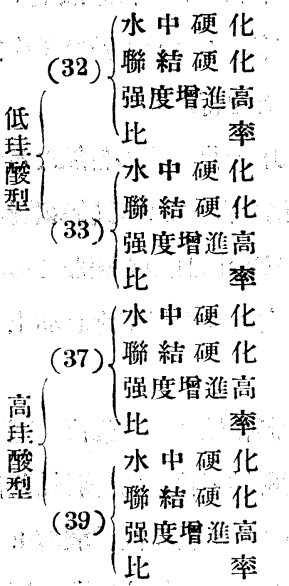

抗 張 $力\left(\mathrm{~kg} / \mathrm{cm}^{2}\right)$

\begin{tabular}{|c|c|c|c|c|c|}
\hline 1 週 & 21 & 4 & 8 & 13 & $26 "$ \\
\hline 23.6 & 25.6 & 28.0 & 30.2 & 30.9 & 32.2 \\
\hline- & 39.7 & 46.5 & 45.0 & 41.0 & 40.8 \\
\hline- & 14.1 & 18.5 & 14.8 & 10.1 & 8.6 \\
\hline - & 155 & 166 & 149 & 133 & 127 \\
\hline 25.6 & 27.3 & 28.7 & 29.7 & 32.0 & 32.6 \\
\hline- & 46.4 & 48.3 & 46.5 & As.7 & 42.7 \\
\hline- & 19.1 & 19.6 & 16.8 & 11.7 & 10.1 \\
\hline- & 170 & 168 & 157 & 137 & 131 \\
\hline 27.1 & 30.6 & 35.0 & 36.7 & 37.8 & 28.1 \\
\hline- & 36.0 & 42.0 & 45.8 & 44.5 & 44.8 \\
\hline - & 5.4 & $\because 7.0$ & 9.1 & 6.7 & 6.7 \\
\hline- & 118 & 120 & 125 & $11 \%$ & 117 \\
\hline 27.5 & 30.2 & 33.5 & 34.8 & 37.1 & 38.8 \\
\hline- & 35.2 & 41.4 & 41.2 & 42.9 & 44.2 \\
\hline- & $\tilde{5} .0$ & 7,9 & 6.4 & 5.8 & 54 \\
\hline- & 117 & 121 & 118 & 116 & 114 \\
\hline
\end{tabular}

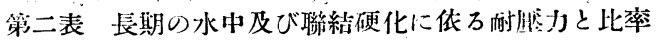

セメント試料 硬化法

種别番號と比率

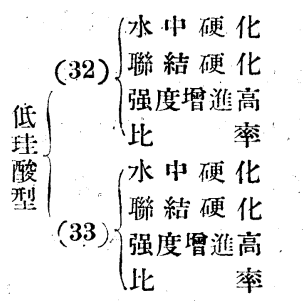

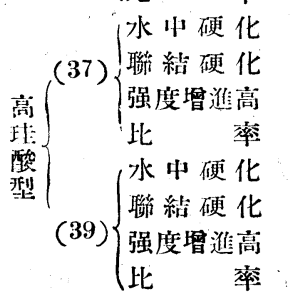

1 灌

379

$-$

$-$

$-$

484

$484 \quad, 520$
$-\quad 572$

$\therefore \quad \div 2$

- 110

35 )

$-$

$-$

$-$

378

$-$

$-$

435

$5 \cdot 1$

126

129

481

584

103

121
酎 维 力 $\left(\mathrm{kg} / \mathrm{cm}^{2}\right)$

$\begin{array}{rrrr}4 & 8 & 13 & 26 \\ 532 & 569 & 588 & 598 \\ 624 & 623 & 636 & 629 \\ 102 & 51 & 51 & 31 \\ 120 & 110 & 108 & 115 \\ 538 & 518 & 553 & 593 \\ 658 & 65 t & 651 & 644 \\ 120 & 106 & 97 & 91 \\ 122 & 117 & 117 & 114 \\ 551 & 631 & 678 & 681 \\ 632 & 625 & 640 & 649 \\ 71 & -6 & -33 & -32 \\ 113 & 49 & 91 & 95 \\ 596 & 6.6 & 680 & 686 \\ 612 & 662 & 637 & 638 \\ 16 & 16 & -43 & -48 \\ 103 & 102 & 94 & 93\end{array}$

郎古此の第一及び第二表の結果に就て見るに低理酸型セメシトに於ては聯紨硬化强度は賞に同一材敔命の水中 硬化强度より大なるに塏して高理酸型セメントに於ては 8 週或は 13 週以後は聯結硬化强度が水中硬化强度よ り小なる值となるは特に注目すべき笘なり是等の原因として考ふべきは低理酸型セメントの水中硬化が 4 週以

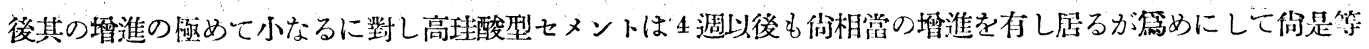
の聯結硬化强度は网型種共に 4 週又は 8 週より以後颉えど大差なく而も低珪酸型セメントの聯結硬化强度は 2 週より以後は總べて水中硬化强度より大なるを以つて特に聯結硬化に存利なるものなり

斯くの如く低珄酸型セメントの水中硬化が 4 週又は 8 週以後に於て其の霄淮の極めて小なるは特に注意要要 


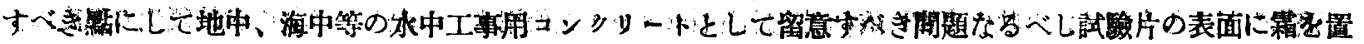

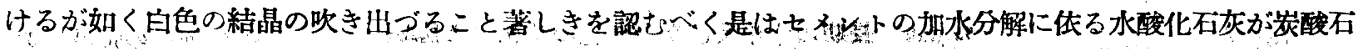
灰となり又其の一部は水酸化石灰として水にて溶出せらるるもの著しく之か强度に影響するをころ大なるが瓷 め水中硬化强度の小なるに對し1 週以後空中硬化を行ふ聯結硬化には此のこと無く却つて有利こし せ共の强度 大なるを得るものなり

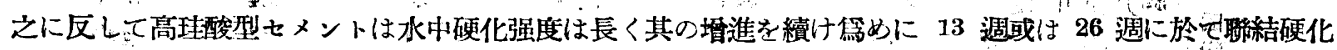
强度を浚駕守るに至る篮し聯結硬化に於てはセメントの硬化に必要なる加水分解に加はる氷は最初の1週間の

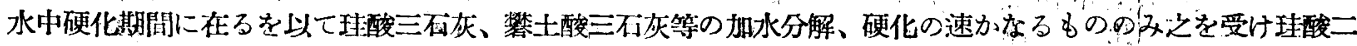

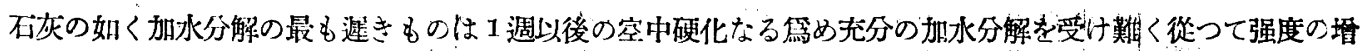
進の止まることは聯結硬化の 4 週以後に認むるに對し水中硬化は此の理酸二石灰の加水分解、硬化淮行の結果

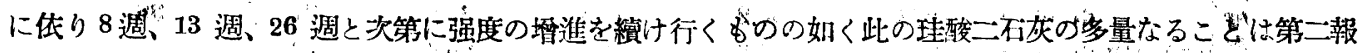

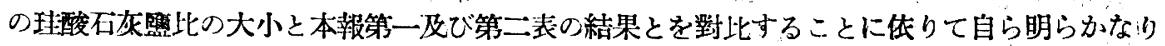

次に第一圖より第四冏を以て是等第一及で第二表の結果を各種セメントに就て胃示す机ば兩型種セメントが 聯結硬化强度に如何に明膫なる差翼を示すが知り得べく空中工事なる建築工事と水中、地中、海中工事なる

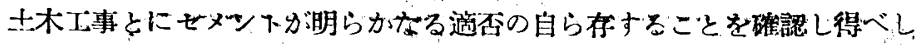
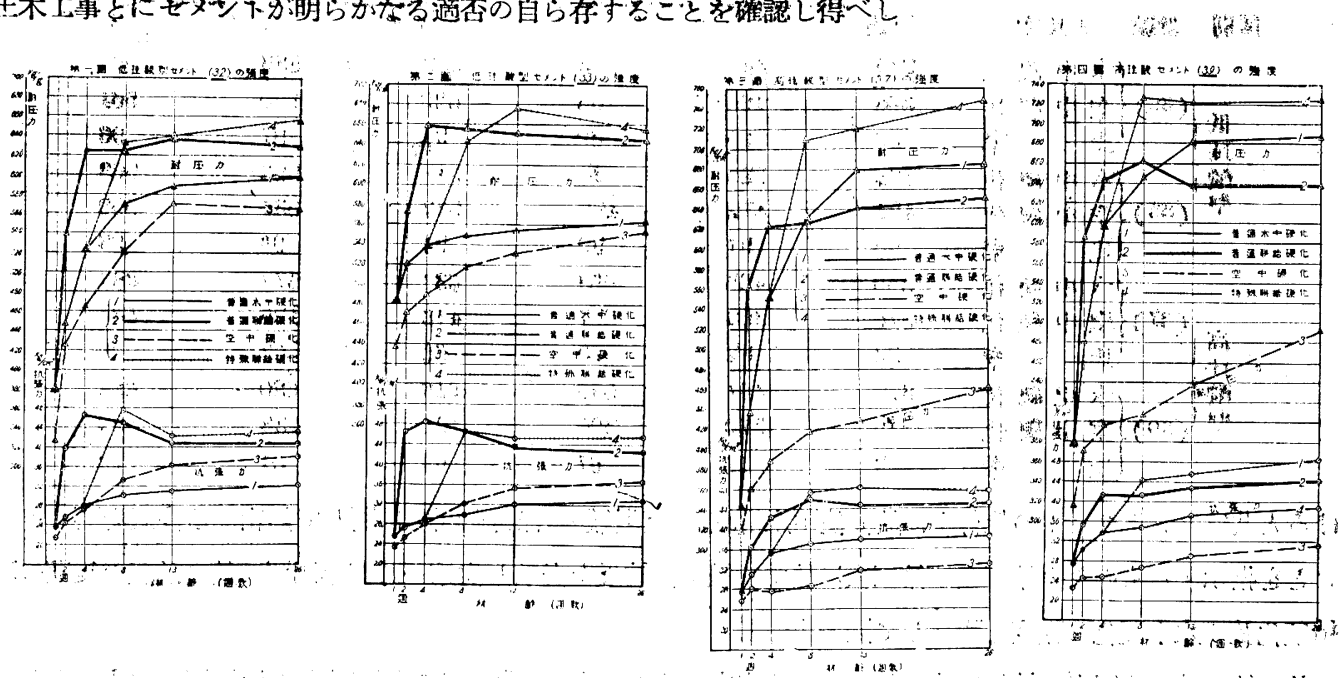

III 長期の空中硬化の强度

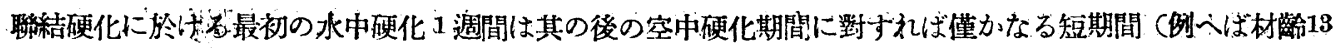

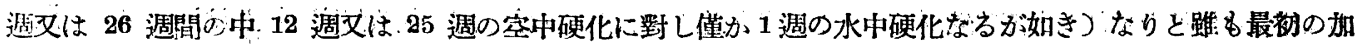

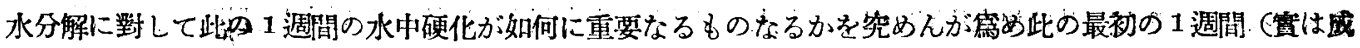

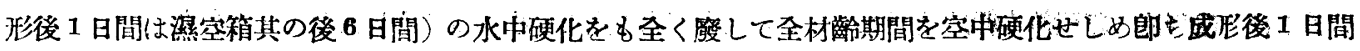

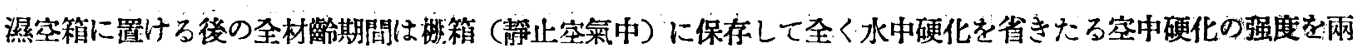
型種セメン・ケの2 種宛に就て比較試驗したり其の結果は次の第三及び第四表に示す如く何れる同一材龄め聯結

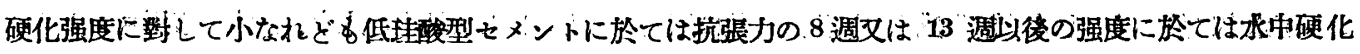
强度よりも大となり高珄酸型セメントは之に友して水中硬化强度よりる常に小なる数值を與ふるか如き㬎著な 


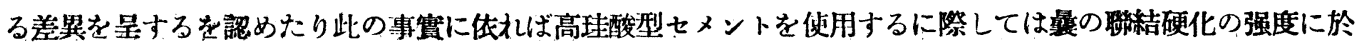
第三表 長期の水中及び空中硬化の抗張力と比率

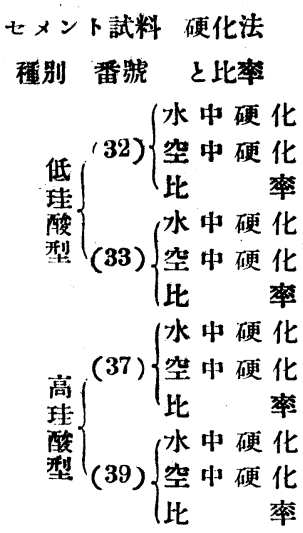

\begin{tabular}{|c|c|c|c|c|c|}
\hline 1造 & 211 & 4 & 8 & $13 "$ & 26 \\
\hline 23.6 & 25.6 & 28.0 & 30.2 & 30.9 & 32.2 \\
\hline 21.4 & 24.3 & 27.5 & 33.4 & 36.4 & $\mathbf{3 8 . 0}$ \\
\hline 91 & 95 & 98 & 111 & 117 & 118 \\
\hline 25.6 & 27.3 & 28.7 & 29.7 & 32.0 & 32.6 \\
\hline 23.2 & 25.1 & 27.9 & 32.0 & 35.2 & 36.7 \\
\hline 91 & 92 & 97 & 108 & 110 & 113 \\
\hline 27.1 & 30.6 & 35.0 & 36.7 & 37.8 & 38.1 \\
\hline 25.4 & 27.9 & 27.2 & 28.1 & 31.5 & 32.6 \\
\hline 94 & 91 & 78 & 77 & $83^{\circ}$ & 86 \\
\hline 27.5 & 30.2 & 33.5 & 34.8 & 37.1 & 38.8 \\
\hline 22.4 & 24.2 & 24.5 & 26.9 & 29.1 & 31.1 \\
\hline 81 & 80 & 73 & 77 & 78 & 80 \\
\hline
\end{tabular}

第四表 長期の水中及び空中硬化の耐成力と比率

ヒメント試料 硬化法

種别番號 と比率

低 (32) $\left\{\begin{array}{l}\text { 水中硬化 } \\ \text { 空中硬化 } \\ \text { 比率 }\end{array}\right.$

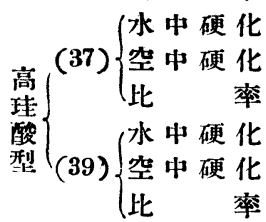

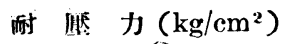

\begin{tabular}{|c|c|c|c|c|c|}
\hline 1 邀 & $2 "$ & $4 "$ & 811 & 13 & $26 "$ \\
\hline 379 & 446 & 522 & 569 & 583 & 598 \\
\hline 326 & 425 & 465 & 520 & 570 & 564 \\
\hline 86 & 95 & 89 & 91 & 97 & 96 \\
\hline 484 & 520 & 538 & 518 & 553 & 563 \\
\hline 437 & 472 & 439 & 517 & 531 & 552 \\
\hline 90 & 91 & 90 & 94 & 96 & 98 \\
\hline 350 & 435 & 551 & 631 & 678 & 681 \\
\hline 316 & 358 & 397 & 416 & 425 & 461 \\
\hline 90 & 82 & 70 & 66 & 63 & 68 \\
\hline 378 & 481 & 536 & $6 \pm 6$ & 680 & 688 \\
\hline 315 & 370 & 396 & 404 & 438 & 492 \\
\hline 83 & 77 & 67 & 63 & 64 & 72 \\
\hline
\end{tabular}

けると共にコンクリートの施行上に於て使用水量或は濕潤狀態の保持期間等に關して周密なる注意を要すべき ことを指示するものなり第三及で第四表に於て比較試驗結果を表示し占第一乃至第四圖に於て前記の長期の聯 結硬化及び水中硬化の强度と對此して圖示すべし

此の第三及び第四表の結果に於て認むる如く空中硬化の强度は 4 週又は 8 週以後其の增進極めて小なり殊に 高理酸型セメントに於ては水中硬化强度との差大なり是は最初の成形の際の水、1 週間水中硬化中の水等は主 として攀土酸三石灰、珪酸三石灰の如き加水分解の速かなるものの加水分解に消費せられ强度の發生も4 週位 迄は相當に增淮を見れども高珄酸型セメントに多き珠酸二石灰の加水分解に体る强度の發生は通常 3〜1 週以 後と考へらるるを以て其の加水分解に與ふべき水の不足なる空中硬化法に於ては 4 週以後强度の增進の㙷著な らざるは勿論强度の絕對値も低珠酸型セメントの空中硬化强度より小なるは蓋し當然のことなり

倘低珪酸型セメントに於て 8 週又は 13 週より水中硬化と空中硬化の强度の殆んど接近し來る事實より前節 にも述べたる如く水中硬化强度の增進が 4 週又は 8 週以後極めて小なるが笉めにして此の理由は低珪酸型セメ ントが水中に於て其の加水分解生成物の溶出其の他に原因するものにして地中、水中、海水工事用コンクリー トとして充分の注意を拂ふべくそに對しては珄酸質混和仂の使用等は考慮すべきところなるべし 


\section{IV 長期つ特殊聯結硬化の强度}

第二節に於ては普通緅結硬化法の最初 1週水中硬化の後の空中硬化期間を 3 週より延長したる長期聯結硬化 の强度が问一材蕚命間水中硬化の强度に對する增進率を兩型種セメントに就て比較研究し低珪酸型及び高珪酸型 セメントの化學成分の差巽と極めて密接なる關俰を有することを確登しホり本節に於ては此の最初 1週間の水

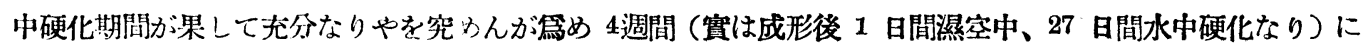
延長したる後初めて空中硬化すること 4週、9週、22週となし都合全材踰 8 週、13 週、26週として前數節の試 驗の同一村㰸の水中文は普通聯結硬化或は空中硬化の强度等と比較したり

此の特梠の聯結硬化に依机る强度は次の第五表に示す如く其の强度は 1週水中硬化後空中硬化を聯結したる 普通聯結硬化上りは常に大なる强度を與ふ然れども 13 週、26 涸の長期材䒝となるにつれて兩者共に强度は 幾分低下の氣味むり更に此の特殊聯結硬化に依り 4週呾迄水中硬化を延長したる强度は普通聯結硬化毁ち僅か に1週間のみの水中硬化後空中硬化に聯結したるものの强度に比して常に幾分大なりと雖も其の差極めて小な る事實は此の水中硬化の期間は既に 1週間を以て略充分にして 4週間の如く長期の水中硬化を必要とせざるこ とを意味するものの如し此の事實はセメントモルタル、コンクリート等の施行に於て濕潤狀態に保持すべき期 間は略1〜2週問以內を以て充分なることを示するのなり而して此の期間の濕潤就態を是非とも必要とすること 第三節の突中硬化つ久の强度と第二節の普通聯結硬化及び本節の特殊聯結硬化の强度等を比較研究すること

\section{第五表 長期の特殊聯結硬化の强度と比率}

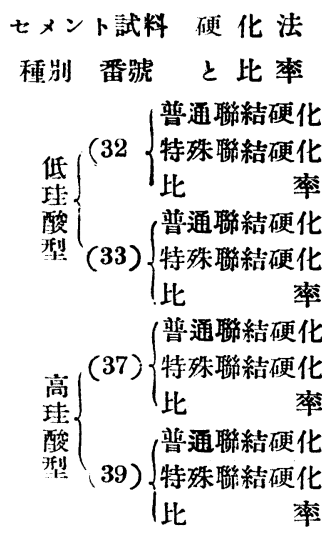

\begin{tabular}{|c|c|c|}
\hline \multicolumn{3}{|c|}{ 抗張力 $\left(\mathrm{kg} / \mathrm{cm}^{2}\right)$} \\
\hline 8週 & $13 \mu$ & $26 "$ \\
\hline 45.0 & 41.0 & 40.9 \\
\hline 47.5 & 42.1 & 43.0 \\
\hline 106 & 103 & 105 \\
\hline 46.5 & 43.7 & 42.7 \\
\hline 46.5 & 45.2 & 45.5 \\
\hline 100 & 103 & 107 \\
\hline 45.8 & 44.5 & 44.8 \\
\hline 47.0 & 48.2 & 47.4 \\
\hline 103 & 108 & 106 \\
\hline 41.2 & 42.9 & 44.2 \\
\hline 44.1 & 45.5 & 48.7 \\
\hline 107 & 106 & 110 \\
\hline
\end{tabular}

\begin{tabular}{|c|c|c|}
\hline \multicolumn{3}{|c|}{ 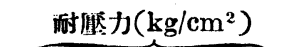 } \\
\hline 8週 & $13 "$ & 26 \\
\hline 623 & 636 & 629 \\
\hline 632 & 640 & 656 \\
\hline 101 & 101 & 104 \\
\hline 654 & 650 & 644 \\
\hline 642 & 676 & 654 \\
\hline 98 & 104 & 102 \\
\hline 625 & 640 & 649 \\
\hline 708 & 719 & 751 \\
\hline 113 & 112 & 116 \\
\hline 662 & 637 & 638 \\
\hline 726 & 723 & 724 \\
\hline 110 & 113 & 113 \\
\hline
\end{tabular}

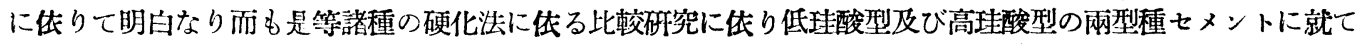
其の差異の極めて顯著なるは如何に七メントの化學成分の差異に負ふところ大なるかを明確ならしもるものに してセメントモルタル、コンクリート工事の使用セメントに就て周密なる注意を必要とすることを示するのと いふべし是等諸種の硬化法の强度比較の便宜上本節の特珠聯結硬化の强度をも前數䬦の結果と共に第一乃至第 四圖に納めたり

更に注意すべき默は第五表の高理酸型セメントに於ては特殊聯結硬化の方が普通聯結硬化よりも强度の可成 大なる點が低珐酸型セメントの場合と晎る點にして之れは高理酸型セメントは 1 週の水中硬化のみにては稍 不充分なること低珪酸型セメントよりは著しく2週乃至 4 週水中硬化の方が一㸴有利なるを示し加水分解の䉆

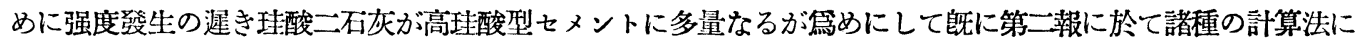
依りて數量的に確めたるこころを本報所載の諸種の硬化法に依る强度試驗に依りて更に確證したるものなり 


\section{總}

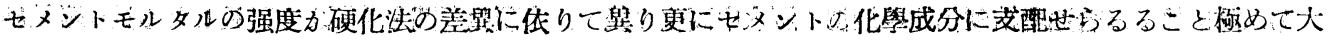

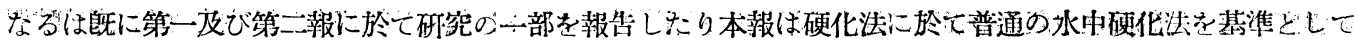

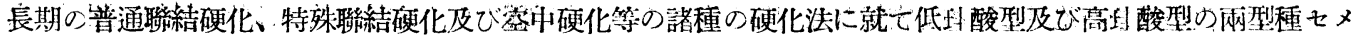
ントを比較䂧究したる結果老報告したるものにして其の概要次の如し

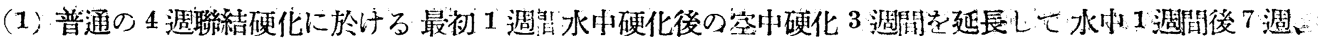

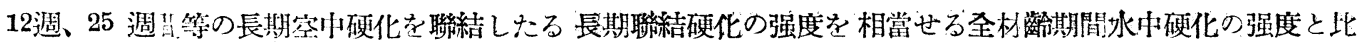
較對照して低玨酸型セメシトは水中硬化より聯結硬化の方强度大なるに對し高琲酸型セメントは8 週文は 13 恖より聯結硬化强度が却つて小なり其の主なる理由は低珪酸型セメントは長期の水中硬化は加水分解生成物の

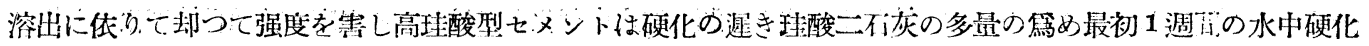

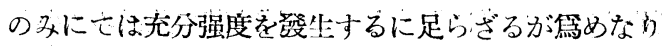

(2) 全材齡期間呛水中硬化無き長期の空中硬化の强度は低理酸型セメントに於て 8 週女は 13 週以後水中硬 化强度より大なるに對し高理酸型セメシトに於ては水中硬化上り管に薯しく小なり其の理山は前記の（1）の長 期聯結硬化試驗の場合と同じく低理酸型セヌントが水中硬化に渻しく不利なるに對し高理酸型セメントに於て は其の硬化に充分の水分、濕分を必要とすること低珄酸型セメントより漖しきが篇めなり

（3）特殊聯結硬化法として前の（1）普通聯結硬化の1週水中硬化を4週闒に延長し然る後空小硬化したるも のに於ても兩型種セメントに就て明らかなる美琵を示寸刨も低玨酸型セメントに於ては普通聯結硬化、特殊聯

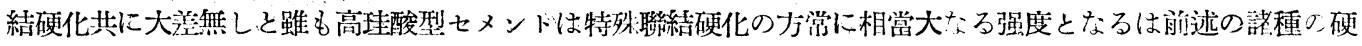

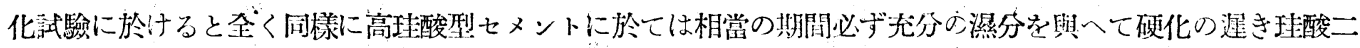

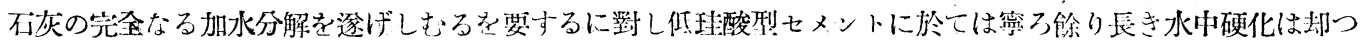
て强度を畫するもの多きが䉆めなり

是等數種の晎なれる硬化法の比較砄究に依り一明らかなる如くセメントモルタル、コンクリート等の施行上: セメントの化學成分の如何に就ては允分の注意と考慮とを拂ぶ゙きは勿論其の敒用工事の種類に就ても充分七

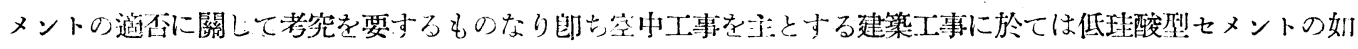

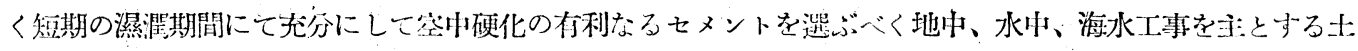
木工事に於ては長期の水中硬化を不利とする低理酸型セメントを避けて高理酸型セメントの如く空中硬化には 不利なるも水中硬化に於て次第に充分なる强度の墂進を件ふが如きセメントを選ぶべきものにして既に第一及 び第二報に報告したるセメントの化學成分㷠にセメントの水硬素たる理酸、攀士、酸化鐵、不灰等の望的關係

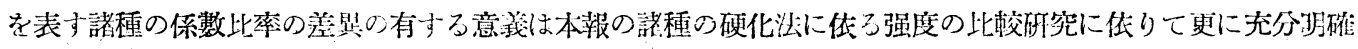
ならしむるを得たり

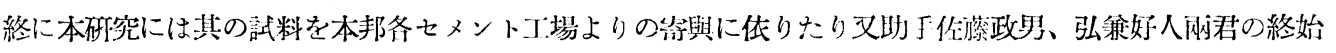
熱心なる助力に負ふとこつ多し渚都は茲に厚く謝意を垡するものなり 